\title{
Shades of FDI Capital, Business Group Affiliation and Excess Value Creation
}

\author{
Kunal $^{1 *}$, B. V. Phani² \\ ${ }^{1}$ Indian Institute of Management, Kashipur, India \\ ${ }^{2}$ Department of Industrial and Management Engineering, Indian Institute of Technology, Kanpur, India \\ Email: *kunal@iimkashipur.ac.in
}

How to cite this paper: Kunal and Phani, B.V. (2018) Shades of FDI Capital, Business Group Affiliation and Excess Value Creation. Theoretical Economics Letters, 8, 3509-3536.

https://doi.org/10.4236/tel.2018.815216

Received: October 22, 2018

Accepted: December 4, 2018

Published: December 7, 2018

Copyright (c) 2018 by authors and Scientific Research Publishing Inc. This work is licensed under the Creative Commons Attribution International License (CC BY 4.0).

http://creativecommons.org/licenses/by/4.0/

(c) (i) Open Access

\begin{abstract}
This research work is focused on effect of business group affiliation on firm with different shades of FDI capital such as technology, capital and competitiveness defined on the basis of FDI policy tools designed by Indian policy makers. The analysis reveals negative effect of business group affiliation on excess value created by firm using competitiveness shaded FDI capital. This empirical evidence supports that tunneling effect of business group affiliation is highly significant in a firm with competitiveness shaded FDI capital. Once, profitability, asset utilization and growth opportunity is controlled, the tunneling effect of business group affiliation becomes highly significant in firm irrespective of the shades of FDI capital. This is in support of study reported by Bertrand et al. (2002) claiming that tunneling effect is part of non-operating profit. There is strong evidence that FDI investors' fund is expropriated by domestic business group when host economy has sufficient capital and technology and foreign investor is intending to create excess value on account of their higher efficiency.
\end{abstract}

\section{Keywords}

FDI, Business Group Affiliation, Propping, Tunneling Effect, Confirmatory Factor Analysis, Excess Value Creation

\section{Introduction}

Earlier foreign direct investment (FDI) has been considered as the most effective way of exploitation of host economy (according to dependency school) however now-a-day, this is perceived as changing agent for growth of host economy. In present scenario, emerging economies consider as a bundle of capital, technology and managerial efficiency which can be infused to boost growth of home 
economy. Accordingly, policy makers are designing policy instruments to supplement domestic resources of capital, technology and competitiveness in domestic economy by using FDI capital. In order to facilitate this process, policy makers are developing mechanism to channelize technology in technology deficient industries, capital in capital deficient industries and managerial efficiency in efficiency deficient industries. Such mechanisms are developed with underlying policy that performance of industry gets improved by infusing specific scarce resources in industry deficient of the same. In this mechanism, the scarce resources required for growth of a specific industry has been considered as basis for designing policy instruments and accordingly FDI capital is regulated in the host economy. These policy instruments have been used for classification of FDI capital. This resulted into four categories of FDI capital i.e. capital shaded FDI, technology shaded FDI, security shaded FDI and competitiveness shaded FDI. Out of these four categories, three categories of FDI capital have been identified based on the priority of scarce factor to be infused in an industry. Security shaded FDI capital has not been considered in this study due to unavailability of data. This classification is further supported by policy documents of host economy government, which is used for designing policy tools. These policy instruments are helpful in infusing desired component of FDI capital in a specified industry. The process of infusing these factors is interplay of demand (as per need of industry) and supply (competitive advantage of FDI investors). In this research work, the shades of FDI capital have been defined from perspective of home economy with competitive advantages in terms of technology, capital and efficiency (competitiveness) in a specified industry. Accordingly, three shades of FDI capital are considered as technology, capital and competitiveness.

Different shades of FDI capital are used by two different sets of firms i.e. business group affiliated (BG) and non-business group affiliated (NBG). In another words, it can be said that foreign investor providing FDI capital has two options of investing FDI capital in host economy i.e. making investment in BG firms or NBG firms. This research work excludes the possibility of making investment with $100 \%$ ownership. Therefore, foreign investors weigh option of investing in BG and NBG firms.

FDI investor investing in BG firm gets benefited in terms of having access to internal capital market, using pool of talents, expertise and fund of business group leading to reduction in cost of capital and improvement in performance. These unique features of business group affiliation is expected to have propping effect which can be explained as the process of transferring resources owned by business group to the firm with FDI capital. The resources owned by business group can be considered as private resources of the business group and transferring such private resources to the firms with FDI capital can be considered as propping effect [1] [2] [3] [4] [5]. Opposite to this phenomenon, expropriation of funds that rightfully belong to other shareholders has been also reported in literature [6]-[14]. The phenomenon of expropriation of resources or tunneling resources out of firms is popularly known as tunneling effect. Tunneling effect is 
widely reported in countries with weak legal protection for investors [6] [7]. Tunneling resources out of the firm is possible by sharing of resources, having strategic ties with group members leading to lower efficiency, intra-group financing, cross-subsidization and misallocation of resources [15].

In this research work, propping and tunneling effects have been conceptualized from the perspectives of FDI investors. These two phenomena are possible in NBG firm by transferring private asset of domestic investors to the firm (propping effect) or expropriating fund that rightfully belong to FDI investors (tunneling effect). In case of BG firm, private asset is not only that owned by domestic investors better to say partner but also assets or resources owned by business group. These assets are (both tangible and intangible) existing internal capital market, pool of talents, expertise and fund of business group leading to reduction in cost of capital and performance improvement factors. In case of tunneling, expropriation of resources can be done by diverting of resources to other group firm, having strategic ties with group members leading to lower efficiency, intra-group financing, cross-subsidization and misallocation of resources. Business group is important aspect of emerging economy [16] since they possess majority of the productive asset ${ }^{1}$.

Against this background, the research question is defined as "Whether business group affiliation increases value creation (propping effect) or decreases value creation (tunneling effect) of firm with different shades of FDI capital in emerging economy?"

In this research work, the effect of business group affiliation on different shades of FDI capital has been analyzed in emerging economy. This analysis has used dataset from Indian economy and it is observed that business group affiliation has tunneling effect in competitiveness shaded FDI capital is highly significant. In technology shaded and capital shaded FDI capital, business group tunneling effect is significant after controlling value enhancing factors like profitability, growth opportunity and asset utilization. These findings answer a number of questions in the area of international business and corporate finance.

This research work provides a framework for classification of FDI capital using policy instruments. This is unique contribution towards international finance literature. It is also important in current scenario as economy planners are setting their own priority to infuse foreign capital, technology or competitiveness in their domestic economy. Very first, this objective is being set and then the policy instruments are designed to serve the purpose.

Another contribution is identification of behavior of domestic business group towards FDI investors. This research work also sheds light on the preference of FDI investors in host economy. The behavior of domestic business group and preference of FDI investor play significant role in international finance which is the core of international business.

${ }^{1}$ More than $70 \%$ of the productive assets are possessed by business group affiliated firms in India. This calculation is based on assets of listed firms in India. The dataset has been extracted from Prowess databases maintained by Centre for Monitoring Indian Economy (CMIE) (http://www.cmie.com/). 
There is strong evidence that FDI investors' fund is expropriated by domestic business group when host economy has sufficient capital and technology and foreign investor is intending to create excess value on account of their higher efficiency. It is advisable for efficient FDI investors to prefer stand-alone firm than business group. Other FDI investors should make investment in business group with high profit, growth and using asset to the maximum extent.

This paper consists of seven sections. Section 2 discusses different shades of FDI capital, which is linked to the FDI policy framework adopted by Indian government. Section 3 deals with effect of these shades of FDI capital on excess value created by firm. This discussion is further extended to analyze effect of business group affiliation on excess value created by firm with different shades of FDI capital. This section gets concluded with presentation of hypotheses. Section 4 deals with dataset while Section 5 covers methodologies used for analysis. Section 6 presents results and discussion is done in section, which is followed by conclusions (Section 8).

\section{FDI Policy Framework: Defining Shades of FDI Capital}

This research work is focused on emerging economy and Indian economy is considered as representative emerging economy. The FDI policy framework adopted by Indian government is considered as basis to define shades of FDI capital. More often Indian Government intends to open specific industry in regulated environment. Allowing FDI for specific industry is critical decision of Indian government and there is a separate list known as negative list, which covers all the industries where FDI is prohibited. The purpose of Indian government to make domestic industry competitive in international market gets served through spillover effects.

India's FDI policy is combination of restrictions in three dimensions for any given industry i.e. capital flow restriction, ownership restriction and repatriation restriction. The rationale behind these three forms of restrictions is provided in the policy documents of the government. These restrictions are meant to channel the flow of FDI with capital, technology and managerial implications to industries, which require them. For instance in industries wherein huge capital investments are required and where there is limited or no domestic players exist, restrictions are not imposed in the first two dimensions i.e. capital and ownership (with a limited restriction on the third dimension). In such identified industries, FDI investor can directly invest without prior government permission and also have full ownership, but repatriation or exit is not allowed in the first three years of operation.

The above mentioned policy instruments adopted by Indian government are summarized in Table 1. The elaboration of rationality of these policy instruments in light of need of industries and characteristics of investors is mentioned in the policy document prepared by government authority. These policy documents explicitly mention the objective of opening a specific industry for FDI and 
Table 1. FDI Policy instruments for Indian government and investor characteristics.

\begin{tabular}{|c|c|c|c|c|c|c|}
\hline \multicolumn{3}{|c|}{ Need of Industry } & \multicolumn{3}{|c|}{ Policy Instruments } & \multirow[b]{2}{*}{ FDI Investor characteristics } \\
\hline Capital & Technology & $\begin{array}{l}\text { Managerial } \\
\text { Skills }\end{array}$ & $\begin{array}{l}\text { Ownership } \\
\text { restriction }\end{array}$ & $\begin{array}{l}\text { Capital flow } \\
\text { Restriction }\end{array}$ & $\begin{array}{l}\text { Repatriation } \\
\text { restriction }\end{array}$ & \\
\hline $\mathbf{P}$ & S & S & $x$ & $\sqrt{ }$ & $\sqrt{ }$ & $\begin{array}{l}\text { - Having large capital to invest } \\
\text { - Able to raise large capital at low cost }\end{array}$ \\
\hline S & $\mathbf{P}$ & S & $\sqrt{ }$ & $x$ & $x$ & $\begin{array}{l}\text { - Developed superior technology } \\
\text { - Less capital is required }\end{array}$ \\
\hline S & S & $\mathbf{P}$ & $x$ & $x$ & $x$ & $\begin{array}{l}\text { - Interested in market penetration, integrating global operation } \\
\text { - Possessing superior managerial skills }\end{array}$ \\
\hline
\end{tabular}

P: Primary need; S: Secondary need; $x$ : No restriction; $\sqrt{ }$ : Restriction is required.

policy instrument used. Accordingly, the industries can be categorized based on the restrictions imposed into four categories:

1) Industries with Capital restriction (no ownership restriction)

a) Industries with Capital and Repatriation restriction

2) Industries with Ownership restriction (no capital restriction)

3) Industries without any restriction (neither ownership nor capital)

4) Industries with both Capital and Ownership restriction

In this research work, first three categories of industries are considered since the industries, which fall under the last category, are primarily related to national security and defense. These do not form part of this study, since most of the firms in these industries are not listed and the financial data is not available in the public domain.

\subsection{FDI Investment Industries with Capital Flow Restriction}

Restriction on capital flow has been imposed in the form of industry specific route for FDI approval i.e. automatic route and government route. FDI approval through automatic route is provided by default, as the investor needs to just inform the relevant authorities and in India's case primarily RBI. This route virtually does not offer any restriction to capital flow. On the other hand FDI approval through government route vests the competent authority with substantial discretion with respect to restriction of capital flows in these industries and sectors. The restriction or the discretionary powers vested with the regulator also has two inter-related dimensions of control, it not only controls the magnitude of investment which can be brought in by an investor in a particular firm but also the number of such investors to be allowed in each sector. In many cases the investments allowed in these sectors/industries are non-competitive in nature due to its uniqueness. For example if an investor is allowed to invest in a road project then there is no possibility of investment in another road project in same geographical region.

Indian FDI policy framework is designed to control capital flow in industries having potential of offering large size investment opportunity. In these industries capital restriction is impose to avoid speculative investment. There is possibility of acquisition of land for construction of residential complex; township 
etc., both Brownfield and Greenfield projects, in anticipation of rise in price upon completion of projects due to limited supply. Most of these projects are unique and investor behavior may be monopolistic in nature. Lack of capital with domestic investors ceases such possibility of speculative investment and there is no need to restrict domestic investors in making investment. However, there is a fair chance that foreign investors with large capital raised at low cost will use such speculative investment opportunity, which needs to be avoided to control asset price bubble. This problem may be further accentuated in terms of price and affordability of local residents in case of large scale acquisition of real estate by foreign investors. This restriction is also by virtue of partial capital account convertibility in Indian economy. In addition to controlling meso-level effect, this restriction also helps in controlling negative effect of large capital inflow at macro level i.e. volatility of real exchange rate [17] and crisis of balance of payment (BoP) as experienced by South Asian countries in1997 [18].

Given the above substantial discretionary powers have been vested in the regulator to control capital flow in infrastructure sectors like roads (highway), bridges, dams, development construction project \& township, residential housing and other capital intensive infrastructure projects.

\section{Industry with Capital and Repatriation Restriction}

The condition of minimum period for repatriation of the original foreign investment is imposed in some of capital seeking industry like real estate sector ${ }^{2}$ (Development of townships, Housing, Built up infrastructure and Construction Development Projects). This restriction is a precautionary measure considered by competent authority to prevent speculative capital inflow and ensure availability of the capital as per original commitment of investors. Although, this restriction may discourage investors but the uniqueness of project precludes any competition in market and ensure higher return. In this research work, firms operating in this industry have been pooled with industries with capital restriction.

\subsection{FDI Investment Industries with Ownership Restriction}

Ownership restriction has been considered as policy instrument to encourage strategic collaborations in industries where technology is a more critical resource than capital. It has been mentioned in the policy documents that encouraging foreign investment in these industries along with technology collaboration would allow domestic firms access to superior technologies, increased exports and expansion of the production base ${ }^{3}$. Imposing restriction on foreign ownership of a firm ensures that the domestic partner would gain expertise rapidly resulting into acceleration of spillover effect. These partnerships also help in establishing dynamic relationship ${ }^{4}$ between domestic and foreign industry in terms of

${ }^{2}$ Master circular on foreign investment in India, Annexure 1, page no. 59, accessed on 12 April, 2011, http://rbidocs.rbi.org.in/rdocs/notification/PDFs/15MFI300611F.pdf

${ }^{3}$ Statement on industrial policy, July 24, 1991 (Exhibit No. 5, Para No. 13)

${ }^{4}$ Statement on industrial policy, July 24, 1991 (Exhibit No. 5, Para No. 24) 
both technology \& investment. This will result into benefit of the Indian economy in terms of technology transfer, marketing expertise, modern managerial techniques and promoting exports. As a measure to encourage FDI and technology transfer, FDI ownership has been increased to $51 \%$ in these industries (also known as FERA Industries or Annexure III Industries) on discretionary basis. This increase in ownership has been done with an objective to avoid bottleneck ${ }^{5}$ in bringing new technology due to the lack of controlling ownership ${ }^{6}$.

This is more important for closely held technology by manufacturing firms. In high priority industries, automatic approval helps in facilitating technology transfer agreements and limiting bureaucratic delays in the process. Hiring of foreign technicians and conducting foreign testing of indigenously developed technologies were also set free from the prior approval process ${ }^{7}$. Domestic trading companies (primarily engaged in export activities) were also allowed for 51\% foreign equity investment to encourage export. This was done in addition to government initiatives of extending assistance to foreign trading companies in systematic exploration of world markets through intensive and highly professional marketing activities.

In many industries advanced technologies are not available and which are essential for domestic firms to compete in global market. Indian governments objective to develop these industries through technology transfer and produce high tech products/services has been clearly enunciated in the policy document of FDI opening for Commodity exchange ${ }^{8}$ where FDI will bring the latest technology, modern management skills and best practices. Similarly the telecommunications sector and IT sector were also opened for limited ownership FDI with the intent to enable these sectors to access state of the art technology in these domains. Policy documents also mention the new technology infusion is the prime objective for allowing FDI in Global Mobile Personal Communications by Satellite (GMPCS) ${ }^{9}$, readymade garments sector ${ }^{10}$ and software industry ${ }^{11}$.

\subsection{FDI Investment Industries without Restriction (Neither Ownership Restriction nor Capital Flow Restriction)}

Investment in these industries provides opportunity for foreign investors to full ownership and unlimited capital flow without prior permission (automatic route). The rationale as per the policy documents is to make Indian industry globally competitive. The policy envisages that FDI in these sectors would lead to the introduction of superior quality of products and services given their expertise in international market. It will help in spurring Indian firms to improve the quality of their products and services to remain solvent. For example Terre- 
strial Broadcasting $\mathrm{FM}^{12}$ industry has been opened for FDI to provide superior programs (local content and relevance), quality improvement in service and generating local employment. On the other hand FDI has also been permitted through Export hardware schemes, Electronics Hardware Technology Park (EHTP) Scheme, Software Technology Park (STP) ${ }^{13}$, Export oriented units (EOUS) and Export promotion zones $(\mathrm{EPZs})^{14}$, trading companies with thrust on export ${ }^{15}$ and industries like textile ${ }^{16}$, Aquaculture \& fish/prawn units ${ }^{17}$ etc.

\subsection{FDI Investment Industries with Capital and Ownership Restriction}

The firm operating in this type of industry fall under defense sector ${ }^{18}$ in India and for security reasons, restrictions on both, capital flow and foreign ownership have been imposed. The foreign ownership limit has been kept at minimum level of $26 \%$, which does not offer controlling ownership to foreign investors as per the Company Act, 1956 of India. The negative effect of imposing ownership restriction has been highlighted in discussion paper $^{19}$ issued by Indian government. Indian defense industry has been deprived of access to high-end technologies as original equipment manufacturers (OEMs) are not interested in bringing their proprietary technology due to lack in controlling ownership. These firms are not listed with Indian stock exchanges and hence, not considered in analysis.

\subsection{Implications of FDI Policy Framework}

Given the above, ownership restriction and capital restriction are important FDI policy instruments in context of Indian economy. This study considers these two as major dimensions to be considered for classification of FDI investment industries in terms of their resource requirements and accordingly four different shades of FDI capital are presented in Figure 1. These industries are capital

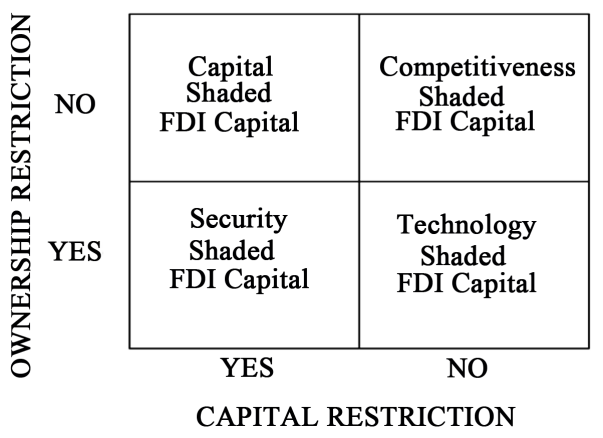

Figure 1. Shades of FDI capital in Indian economy.

\footnotetext{
${ }^{12}$ Press note No. 6 (2005 Series)

${ }^{13}$ Press note No. 5 (1997 Series)

${ }^{14}$ Press note No. 4 (1995 Series)

${ }^{15}$ Press note No. 23 (1991 Series)

${ }^{16}$ Press note No. 1 (2000 Series)

${ }^{17}$ Press note No. 16 (1997 Series)

${ }^{18}$ Press note 4, 2001 Series

${ }^{19}$ http://dipp.nic.in/english/Discuss_paper/DiscussionPapers_17May2010.pdf
} 
seeking, technology seeking, competitiveness seeking and security seeking. Accordingly, FDI capital is classified as technology shaded, capital shaded, security shaded and competitiveness shaded. This research work is focused on three shades i.e. technology shade, capital shade and competitiveness shade of FDI capital.

\section{Hypotheses}

The hypotheses being proposed in this research paper are centered on relationship between shades of FDI capital, excess value creation and business group affiliation. The various aspects of their relationships have been discussed in two stages. At stage one, effect of different shades of FDI capital on excess value created by the firm is discussed. This discussion is presented in the following three subsections of this section i.e. technology shaded FDI capital (3.1), capital shaded (3.2) and competitiveness shaded (3.3). In stage two, this discussion is extended to cover the effect of business group affiliation as presented in subsection 3.4. This section gets concluded with proposing hypotheses against the background of the above mentioned discussion.

\subsection{Technology Shaded FDI Capital and Excess Value Creation}

Restriction on ownership is unique feature of technology shaded FDI capital even it reduces attractiveness of investment for any investor as ownership restriction imposes a control constraint. This ownership reduction forces the foreign investor to work with the domestic partner in exploring synergies, which will enable them to generate superior returns. The possibility of superior returns would depend on the inherent cost efficiencies or technology deficiencies of the domestic partner. The foreign investor would opt to invest wherever cost efficiencies are available without the ownership constraint unless the investor is more interested in exploiting the domestic market which otherwise will not be accessible. Given the above, in case of ownership constraints investment decision by a foreign investor would depend on other factors other than cost efficiencies. Literature clearly identifies that technology superiority of the foreign investor as compared to the domestic partner is a critical factor for investment in any economy in spite of ownership restrictions. The magnitude of technology gap also plays a critical role in nature and timing of the spillover effects as elaborated in literature review earlier. These investors are interested in incentives available due to their possession of superior technologies in spite of ownership constraints imposed by the economy on foreign investment in specific sectors.

Foreign investors have firm specific advantages by virtue of possession of superior technology as strategic asset, which helps in creating higher surplus than non-FDI firms. The surplus generated by these foreign investors consists of two components: 1) output based observable surplus and 2) intangible asset (goodwill, experience etc.) based unobservable surplus [19]. Although, output is independent of ownership control [20] but firm-specific advantage depends upon the 
unobservable costly effort of foreign investors in developing technologies through R \& D, which is directly proportional to its ownership control. Technology is already available with these investors and the product or service utilizing this technology can be made available in the market with minimal investment. In doing so, only the incremental cost of its implementation with domestic partner would be needed, this reduces cost of investor's effort. Investment would flow into the economy as long as this reduction in level of effort compensates the decrease in surplus due to domestic partnership as imposed by regulator. Therefore, in-spite of ownership restriction, technology investors get motivated to make investment in Indian economy from a resource exploitation perspective as long as the magnitude of technology gap is not large enough to delay the time line of superior returns. These investors get benefited through better utilization of raw material, technical skill available in host economy, cost efficient human resource (unskilled worker). These investors also get benefited by virtue of being first mover [21] especially with market-seeking motive in high growth industry. These investors prefer partial ownership with domestic partner [22] and reduce the time of offering product/service by using facilities of incumbent partner [23] Creation of wholly owned subsidiary along with development of adequate production and supply chain capacities delays the entry of foreign investor thus loosing opportunities to capture the market [24]. Since this delay would catalyze the domestic industry to source the technology from a different partner to protect their markets.

In addition to the above, there is also a fair chance of obsolescence of new technology in long term [25], which will reduce the time available to the foreign investor in monetizing the same. Two other dimensions i.e. technology transfer and internal R \& D capability also explain foreign investors' expectation about performance in different time horizons. Foreign investors in possession of new technology can implement in FDI firm through technology transfer at lesser cost compared to developing in-house or acquiring from open market. The return of FDI firm increases due to adoption of new technology, which is further fueled by reduction in technology implementation cost. Foreign investor exploits technological advantages in host economy in collaboration with domestic partner, which facilitates internal R \& D capability of FDI firms in short term. Non-FDI firm either develops their R \& D capability or acquires the technology in the medium to long term (spillover effect), which will gradually erode competitive advantage of FDI firm unless they maintain their technological superiority.

The performance of a firm can also be measured on another dimension which would be the value created by FDI firms. This differs from the superior returns as measured and tested in the previous hypotheses. Excess value creation is considered as an indicator of relative performance. This measure of performance considers capital gain, which is normally excluded while calculating return expressed in terms of accounting measures (ROA, ROE etc.) and equity market (logarithmic return). 
In industry with ownership restriction, value creation is viewed from two aspects i.e. information processing and commercialization (development of new products/services). Uncertainty and equivocality are two important dimensions which explaining role of management of the receiving firm for effectiveness of technology in value creation [26]. The familiarity about technological situation (Uncertainty) and the degree of ambiguity about technology (equivocality) of FDI firm is dependent of managerial ability. FDI firm is proposed to be superior to non-FDI firms on these two criterion.

Technology transfer is focused on a three step process i.e. acquisition of new knowledge or information, converting to commercial products or service and positioning products/service in marketplace [27].

Given the availability of technology with foreign investor of FDI firms, they are in a better position to create more value (internal spillover effect) as compared to domestic firm having no access to these technologies and lacking in innovation. This is an intangible asset for the FDI firm which is difficult to imitate and easy to protect. During initial period, creation of excess value is possible by increasing managerial ability (in terms of familiarity with technology, development of products/services and positioning). With time, technological spillovers effect increases and non-FDI firms will have also access to these technologies and decrease the excess value created by FDI firms.

\subsection{Capital Shaded FDI Capital and Excess Value Creation}

As elaborated in earlier Section 2.1, for industries wherein capital restriction strategy has been implemented, the investor is faced with the limitation in the magnitude of investment, which can be brought into a specific sector/industry. This limitation is incentivized by also limiting competition in these sectors with cap on the number of firms who can invest in these sectors. This incentive would limit the volatility of returns to a large extent. Other than this there is also a repatriation limitation, which is imposed wherein, exit is not permitted for a minimum specified period. From the investor point of view only those investors who have access to large capital resources and having longer return horizon would be interested given the incentive of limited competition.

Given the policy constraint on overseas borrowings ${ }^{20}$ and the nature and scale of the projects, domestic investors are constrained by the unavailability of low cost funds, along with lack of relevant experience due to limited operation in international domain. The excess demand of capital in a particular industry increases cost of capital and accentuates the scarcity of capital to other critical sectors/industries thus adversely affecting a balanced economic growth. This increased cost of capital combined with inability of generating revenue stream in short term due to nature of the projects in these sectors/industries accentuates the riskiness of investment.

As opposed to domestic investor, foreign investor has access to low cost capital ${ }^{20}$ Rangarajan Committee, 1993. 
in large amounts due to low interest rates and lack of investment opportunities for savers in their economies. The infusion of foreign capital from these investors in this particular set of industries will relax the financial constraints on the host economy thus reducing gap between demand and supply of capital. This reduction in gap of demand and supply will reduce the interest rates due to the demand supply mismatch and thus the cost of capital for investments in these large projects having long gestation.

This will also reduce the volatility of returns associated with these projects. This reduction in uncertainty of cash flow and decreased risk associated with financing firms reduces the cost of capital and increases the return associated with these sectors/industries. This combined with limited competition would allow for higher returns to these firms in both short term and long term.

Other than the above in these industries, technology is accessible to both FDI and domestic firms however these two different types of firms can be distinguished on the basis of scale \& scope of economies. These sectors/industries require heavy investment during initial periods to create the infrastructure for offering long-term products/facilities. In other words, these investments have long gestation periods due to which revenue streams are delayed with the initial cash flow streams being negative for a longer duration. Another factor is the scale and scope economies in long run inherent in these projects with very limited opportunity of imitation or competition. Given the expertise required and scale and scope of these projects it would be very difficult for these projects to be executed properly in the absence of assistance in terms of technology, capital and expertise. Firms, which have global exposure with access to significant funds, will have a definite advantage and add value to the economy. Most of these projects are in the form of creating non-transferable tangible assets within the host economy.

The objective of FDI firm is to create excess value in long term due to nature of projects as discussed earlier. It is proposed that they will also create excess value in short term due to their long experience in handling international projects.

\subsection{Competitiveness Shaded FDI Capital and Excess Value Creation}

Industries in which a foreign investor can hold $100 \%$ ownership and the investment can be made through the automatic route are primarily industries in which there are experienced domestic players. These players have access to technology and capital in line with any foreign firm interested in investing in these sectors/ industries. These industries are characterized by few well-established players and exhibit monopolistic/oligopolistic characteristics. An investment by a foreign investor in these industries would be able to generate superior returns only if the investor has superior managerial and operation efficiency and expertise along with capital and technology. Once such an investor enters these industries then by default the efficiency of the domestic players would have to improve rapidly to maintain their competitiveness. In other words FDI in these industries is pri- 
marily characterized by managerial and operational efficiencies. This would increase the competitiveness and efficiency of the firms operating in these industries rapidly and the industry will be characterized by high competitiveness.

In this industry, access to all advantage generating factors of production i.e. new technology, capital and superior managerial skills are not a limiting factor for any firm to perform. Given this, it is not possible to differentiate between FDI and non-FDI firms in terms of their performance in the long term. Though there could be marginal differences in the short term within a specific economy. The window for these differences in the short term would be very small and negligible. Since there would be a time lag for operationalizing any FDI in these sectors, in the short term and FDI firm would underperform non FDI firm but the window for this opportunity would be very small or negligible as mentioned earlier. For FDI investor, investment in these sectors will be tenable not because of the possibility of superior returns but because of marginal contribution to their overall returns at the global level.

In industries without capital or ownership restriction, protection of firm's asset specificity is crucial for strengthening its competitive position [28] and hence foreign investors prefer higher ownership control. The exploitation of competitive advantage helps in strengthening its position in the market especially in case of price competition. In these industries, FDI firm outperforms on account of total factor productivity (efficiency) due to technology, capital and better managerial practices. Technology and capital are also available for domestic firms however complacency due to limited number of players reduces their managerial and operational efficiencies. In other words, FDI investment in these sectors/industries would compel domestic firms to adopt latest technology and managerial practices of FDI firms in very short period to stay competitive. In this way, any advantage from FDI investors total factor productivity gets eroded very quickly as non-FDI firm also uses these factors.

Excess value creation is another dimension of discussion regarding the impact of FDI. In industries with no constraint, access of new technology and capital is available to both FDI and domestic firms. These firms can only create value by using human resources, technology and innovation, unit costs economics and the infra-structure and strategy of the firm [29]. Imitation of all these value-creating elements is possible for the non-FDI firms in these industries. Given this any excess value creation by FDI firm would be of a short-term nature.

\subsection{Effect of Business Group Affiliation}

Business group is inferred in the literature as collection of firms with common administrative \& financial controls and crossholdings. They have common brand identity, pool of labor and rely on intra-group financing [30]. Their interlocking facilitates communications about developments in technology, business opportunity and strategy among member firms. Granovetter observes that elimination of contract reneging through social mechanism of member firms further strengthen the ties resulting into increased cooperation [31]. 
In context of Indian economy, large business houses are family dominated with a greater possibility of extracting wealth from other shareholders [32]. These business groups are also suffering from the problem of misallocation of resources resulting into cross subsidization.

Strategically business groups benefit in building and accessing a network for its own interest wherein resource can be easily accessible. It is true to domestic as well as international relationship. The larger business group facilitates the operations and entry in the international market via joint ventures [15]. The business group affiliated firms are capable of enforcing property rights through their reputation or close relationship with bureaucrats. Business group is also in a better position to protect the technology as a core competency of their business. The business group have been proven superior to stand alone firms in terms of accessing the foreign technology. Such foreign technology improves competitive advantage of business group affiliated firms more than stand-alone firm on account of being used by sister firms and complementing with their resources. Against this backdrop, the following hypotheses are presented.

$\mathrm{H}_{0 \mathrm{a}}$ : Business group affiliation increases value creation (propping effect) in firm with technology shaded FDI capital.

$\mathrm{H}_{1 \mathrm{a}}$ : Business group affiliation decreases value creation (tunneling effect) in firm with technology shaded FDI capital.

Business group affiliated firm can access the internal capital market that brings down the cost of capital. Primarily the business group can have access to broad sources namely internal capital market and external capital market. The internal capital market means the capital requirement is satisfied by raising it from the internal source from its member firms, which can be availed in various forms such as actual money, raw material or managerial competency. This is widely reported in literature that accessing funds through internal market is very easy and cheaper for business group member firm and it is also a desired form of source. The availability of internal capital is of greater advantage in comparison to raising the capital from external market. The advantage is two-fold one being availing the capital at lower cost and other is keeping the ownership concentration undiluted. Therefore the controlling stake remains the same across the firms owned by the business group.

Business group member firm can invest surplus cash available with business group in high NPV project. These firms also get supported by other member firms due to higher insider ownership, to avoid dilution in private benefits after firm bankruptcy and hiding negative information about the group [33]. Such financial assistance extended by group members reduces probability of default on the investment and improves return by reducing cost of capital. The intra-group flow of funds also follows tunneling that can have high insider holding for the new firm. Business group affiliated firms in India has more internal capital market [15] and financial assistance is extended by intra-group firm [33]. Business group has advantage of increasing the firm's debt capacity by reducing the risk of the firm's debt, when business segments with imperfectly correlated earnings 
are combined [34]. This effect is also known as co-insurance effect [35] which is visible in diversified firms and is also valid for diversified business group. This increase in debt capacity will lead to increase in tax shields and therefore business group reduces the amount of taxes to be paid. This reduction in tax will further increase performance of the firm. The above discussed features of business group and its member firms, leads to dominant role of business group even in case of joint venture with its member firm. Such dominance of business group deter outside investors and Dahlquist \& Ran report that foreign investors tend to underweight firms with a dominant owner [36].

The business group affiliated firm also gets benefited through diversification because the firm has certain resources that can be profitably deployed outside the industry in which it operates i.e. entrepreneurial skills, technology, requirement of fund for other business venture etc. The business groups reap the benefits from the diversification and definitely reduce the overall unsystematic risk. The member firm stands as an individual entity in the legal system, it gives option for business group to decide whether it would like to bail out the underperforming firm or let it stop its operations to reduce further losses. The predominance of business groups insulates from the pressure of institutional investors and takeover threats although the undisputed controlling rights lies with the institutional investors [37].

The improvement in firm performance due to its affiliation to business group is widely cited in literature and a number of reasons been cited for the same. Institutional void or response to market failure [16], [33], [38] is one of the prominent reason on the basis their ability to mobile capital and labour to the concern firm from other business group affiliates. The frequent interaction between these affiliated firms helps in improving resource allocation and its bargaining power for favorable terms while acquiring financial resources [39]. Such interaction improves co-ordination in investment decision and reduces uncertainty in supplying intermediate goods [40] [41]. The efficiency of these affiliated firms also gets improved on the basis of reduced transaction cost since resources like scarce skilled and managerial talent [42] [43] [44]. The availability of tacit information, due to existence of networks of these business group affiliates, reduce the level of uncertainty and makes situation better for these firms in contract enforcement and opportunity identification [45] [46]. The opportunity search process is also facilitated by disseminating information regarding technology and product developments [47].

The literature cites that business group performance is correlated with the internal capital market and is highly significant when external capital market is imperfect. These firms are less sensitive to their own cash flow than cash flow of the rest of the members while making investment decisions [48] [49] [50]. Internal market of business group provides managerial competency and expertise in various areas that gives advantage to BG affiliated firm in labor market. Internal market of business group provides reputation, brand equity and BG affiliated firm gets benefited in product market [51]. The positive value is generated 
to a particular firm through mimicking the market mechanism by their business groups in incomplete and inefficient market. On this premise, the following hypotheses are presented.

$\mathrm{H}_{0 b}$ : Business group affiliation increases value creation (propping effect) in firm with capital shaded FDI capital.

$\mathrm{H}_{1 \mathrm{~b}}$ : Business group affiliation decreases value creation (tunneling effect) in firm with capital shaded FDI capital.

The business group affiliation helps in increasing value by reducing transaction cost since resources like scarce skilled and managerial talent [42], [43], [44] are shared among group member firms. These firms use tacit information available in their network of group member firms for value creation [45], [46]. The dissemination of information regarding technology and product developments [47] further helps in creation of additional value. Therefore, a positive effect of business group affiliation on excess value created by the firm is expected and the following hypotheses are proposed.

$\mathrm{H}_{0 c}$ : Business group affiliation increases value creation (propping effect) in firm with competitiveness shaded FDI capital.

$\mathrm{H}_{1 \mathrm{c}}$ : Business group affiliation decreases value creation (tunneling effect) in firm with competitiveness shaded FDI capital.

\section{Dataset}

This dataset is extracted from Prowess database maintained by the Centre for Monitoring Indian Economy (CMIE) (http://www.cmie.com/). CMIE uses annual reports especially financial statement of listed and unlisted firms in India. Unlisted company provides data to CMIE on their willingness if request is made for the same. This database is representative of Indian situation as it covers 60-70 percent of organized sector in India, 75 percent of corporate taxes and 95 percent of excise duties collected by the government of India [52]. This database is widely used by researchers including [8] [53] [54] [55] [56].

The policy documents (Press notes of different series) list name of industries opened for FDI and policy instruments (in terms of ownership, capital restrictions). The nature of policy instruments for specific industry also changes (increasing ownership/capital flow restriction) and accordingly year wise changes have been incorporated. These industries are classified into different shades of FDI capital. Prowess database provides name of the industries (5 digit NIC code). This NIC code has been classified into different shades of FDI capital. The dataset of 4635 firms with FDI investment, consist of $61 \%$ of firms with competitiveness shaded FDI capital, followed by $31 \%$ of firms with technology shaded capital. This dataset has 255 firms with capital shaded FDI.

The descriptive statistics of FDI ownership in business group affiliated (BG) and non-affiliated (NBG) firms across different FDI investment categories are presented in Table 2. This table presents the descriptive statistics of FDI ownership in business group (BG) affiliated and non-business group (NBG) firms. 
Table 2. Descriptive statistics of FDI ownership in business groups affiliates (BG)/non-affiliates (NBG) with different shades of FDI capital.

\begin{tabular}{|c|c|c|c|c|c|c|c|c|c|c|c|c|}
\hline $\begin{array}{l}\text { Shades of FDI Capital } \\
\text { and BG/NBG Firm }\end{array}$ & & 2006 & 2007 & 2008 & 2009 & 2010 & 2011 & 2012 & 2013 & 2014 & 2015 & 2016 \\
\hline \multirow[b]{3}{*}{ Technology } & $\mathrm{N}$ & 50 & 49 & 48 & 47 & 46 & 92 & 74 & 72 & 70 & 70 & 70 \\
\hline & $\mathrm{M}$ & 13.94 & 15.70 & 14.18 & 13.94 & 14.55 & 14.52 & 13.57 & 15.24 & 13.08 & 13.08 & 13.08 \\
\hline & $\mathrm{SD}$ & 13.28 & 15.26 & 13.20 & 13.15 & 13.09 & 17.44 & 13.31 & 15.59 & 13.86 & 13.86 & 13.86 \\
\hline \multirow[t]{4}{*}{ Shaded } & $\mathrm{N}$ & 59 & 59 & 64 & 61 & 62 & 120 & 92 & 87 & 85 & 85 & 85 \\
\hline & M & 29.31 & 27.30 & 26.61 & 27.09 & 25.20 & 25.35 & 20.37 & 21.60 & 22.87 & 22.87 & 22.87 \\
\hline & SD & 19.44 & 20.49 & 20.61 & 20.88 & 20.64 & 21.13 & 20.48 & 20.95 & 21.91 & 21.91 & 21.91 \\
\hline & $\mathrm{N}$ & 8 & 9 & 8 & 7 & 9 & 7 & 9 & 11 & 12 & 12 & 12 \\
\hline \multirow{5}{*}{$\begin{array}{l}\text { Capital } \\
\text { Shaded }\end{array}$} & M & 9.14 & 11.01 & 12.23 & 13.07 & 17.47 & 20.04 & 13.13 & 14.68 & 23.08 & 23.08 & 23.08 \\
\hline & $\mathrm{SD}$ & 8.06 & 10.34 & 14.64 & 15.57 & 16.47 & 14.26 & 14.30 & 16.00 & 22.46 & 22.46 & 22.46 \\
\hline & $\mathrm{N}$ & 12 & 12 & 10 & 11 & 10 & 9 & 17 & 16 & 18 & 18 & 18 \\
\hline & M & 17.89 & 16.83 & 19.49 & 21.57 & 23.18 & 29.74 & 29.60 & 30.27 & 30.36 & 30.36 & 30.36 \\
\hline & SD & 15.14 & 15.90 & 18.93 & 18.06 & 22.38 & 29.17 & 30.88 & 29.93 & 28.21 & 28.21 & 28.21 \\
\hline \multirow[b]{3}{*}{ Competitiveness } & $\mathrm{N}$ & 93 & 100 & 118 & 105 & 107 & 92 & 142 & 138 & 133 & 133 & 133 \\
\hline & M & 15.20 & 13.71 & 12.34 & 13.89 & 13.86 & 14.52 & 13.74 & 14.36 & 14.33 & 14.33 & 14.33 \\
\hline & SD & 14.36 & 13.26 & 12.32 & 13.96 & 15.96 & 17.44 & 16.84 & 16.56 & 16.19 & 16.19 & 16.19 \\
\hline \multirow[t]{3}{*}{ Shaded } & $\mathrm{N}$ & 116 & 120 & 123 & 126 & 125 & 120 & 164 & 162 & 161 & 161 & 161 \\
\hline & M & 25.86 & 26.38 & 25.39 & 25.11 & 24.37 & 25.35 & 22.30 & 21.00 & 21.51 & 21.51 & 21.51 \\
\hline & SD & 19.96 & 20.15 & 20.35 & 21.12 & 20.87 & 21.13 & 21.19 & 19.67 & 20.18 & 20.18 & 20.18 \\
\hline
\end{tabular}

$\mathrm{N}=$ Number of Firms, $\mathrm{M}=$ Mean Value, $\mathrm{SD}=$ Standard Deviation.

This table presents, three types of FDI capital in first column, which is further classified in two sub-categories i.e. BG and NBG. The number of firms in data, mean and standard deviation of FDI ownership are presented year wise.

Table 2 shows that mean value of FDI ownership is less in NBG firm than BG firm for all shades of FDI capital. The number of FDI investment is more in NBG firm is more than BG firm in all three shades of FDI capital. The FDI investment is made more in non-business group affiliated firms across and within FDI investment categories. It is observed that FDI ownership in NBG firms is higher than BG firms for all FDI investment categories.

\section{Variables for Excess Value Creation}

Three different excess value multiples i.e. asset multiple, sales multiple and EBIT multiple, have been used to measure excess value in very similar fashion to Berger and Ofek [57]. Asset multiple is defined as the natural logarithm of ratio of actual value to imputed value. Actual value of the firm is defined as the sum of total book value of debt and market value of equity. The imputed value is calculated as firm's asset multiplied by its industry median capital-to-asset ratio. Sales 
multiple is defined as natural logarithm of the ratio of actual value to its imputed value. The imputed value for this multiple is calculated as the sales of the firm multiplied by its industry median capital-to-sales ratio. Similarly, EBIT multiples is calculated as natural logarithm of ratio of actual value to its imputed value. The imputed value for this ratio is defined as firm's EBIT multiplied by its industry median capital-to-EBIT ratio. The firm size is measured by taking natural $\log$ of total assets. This analysis considers EBIT to sales as surrogate measure for profitability of the firm and growth opportunities of the firm has been captured as the ratio of capital expenditure to sales.

Capital expenditure is calculated by taking change in depreciation adjusted net fixed asset of the firm. Net fixed asset value has been calculated after deducting depreciation from the block fixed asset. Therefore, this study has not considered depreciation separately to calculate excess capital expenditure but added back to net fixed asset. Berger \& Ofek have considered depreciation as one of the variable. This value have been considered only if change is more than $5 \%$ otherwise no change. Then calculation of median industry capital expenditure year-wise is done for each industry. The excess capital expenditure is then calculated by subtracting median industry capital expenditure from the capital expenditure value of the firm. The descriptive statistics of these multiples and ratios is presented in Table 3 . The range and mean value of EBIT multiple is more than asset and sales multiple.

The mean excess value expressed as Asset multiple, Sales multiple and EBIT multiple have large variation as reflected from standard deviation. The number of observations for these multiples also differs since values are missing for many firms in the database and these have been removed from the sample.

This research work is focused on comparing excess value created by BG and NBG firms with different shades of FDI capital. The descriptive statistics of excess value created by BG and NBG firms with different shades of FDI capital are presented in Table 4. The mean excess value for BG firms is observed to be less than NBG firms with all shades of FDI capital.

\section{Methodology}

Initially univariate analysis of the measures of excess value created by BG and NBG firms has been carried out to establish the differences between the means of different categories using ANOVA test. One way analysis of variance (ANOVA) is modeled for quantitative data [58] [59] [60]. This method decomposes total variance due to a single source into two components i.e. systematic

Table 3. Descriptive statistics of excess value (multiples).

\begin{tabular}{cccccc}
\hline Excess Value of firm as & $\mathrm{N}$ & Minimum & Maximum & Mean & $\mathrm{SD}$ \\
\hline Asset Multiple & 19,906 & -11.43 & 11.52 & 0.3714 & 1.645 \\
Sales Multiple & 20,147 & -11.09 & 14.10 & 0.4613 & 1.977 \\
EBIT Multiple & 14,350 & -9.24 & 41.41 & 0.8529 & 2.16 \\
\hline
\end{tabular}


Table 4. Descriptive statistics of excess value created by firms with different shades of fdi capital.

\begin{tabular}{cccccccc}
\hline \multirow{2}{*}{$\begin{array}{c}\text { Excess } \\
\text { Value Measure }\end{array}$} & & \multicolumn{2}{c}{ Competitiveness Shaded } & \multicolumn{2}{c}{ Technology Shaded } & \multicolumn{2}{c}{ Capital Shaded } \\
\cline { 2 - 8 } & & NBG & BG & NBG & BG & NBG & BG \\
\hline \multirow{2}{*}{ Asset Multiple } & Mean & 1.21 & 1.03 & 1.19 & 1.09 & 1.44 & 1.19 \\
& SD & 1.38 & 1.43 & 1.36 & 1.34 & 1.77 & 1.59 \\
Sales Multiple & Mean & 1.23 & 1.10 & 1.25 & 1.03 & 1.85 & 1.41 \\
& SD & 1.57 & 1.70 & 1.63 & 1.64 & 2.26 & 2.18 \\
EBIT Multiple & Mean & 1.73 & 1.45 & 1.59 & 1.04 & 1.98 & 1.81 \\
& SD & 2.13 & 1.55 & 1.69 & 1.76 & 1.54 & 1.72 \\
\hline
\end{tabular}

(difference in means of groups) and random effect (variability around group means). Out of these two components of variance, only systematic effect of variance has statistical influence on the given dataset.

Descriptive statistics of excess value created by firm with different shades of FDI capital is presented in Table 4. Prima facie, it appears that capital shaded FDI capital creates higher value than technology and competitiveness shaded FDI capital. The ANOVA test reveals that firm's excess value differs across and within different shades of FDI capital. Two way ANOVA and MANOVA (Wilk's Lambda) tests have been performed to assess the effect of FDI capital and business group affiliation. After establishing this fact, the significance of other control variables is tested by performing regression estimation. The factors observed to be significant in regression estimate have been used for confirmatory factor analysis (CFA).

\section{Results}

The ANOVA test ${ }^{21}$ performed on pooled data reveals that the difference in excess value created by business group affiliated firm (BG firm) and stand-alone firm (NBG firm) is statistically significant (5\% significant level) if it is measured in terms of asset multiples. The mean value of excess value created by business group affiliated firm is observed to be lower than that of stand-alone firm. For excess value measured in terms of sales multiple and EBIT multiple, no statistically significant difference have been observed between BG firm and NBG firm.

\subsection{Competitiveness Shaded FDI Capital}

For competitiveness shaded FDI capital, ANOVA test results shows statically significant difference between excess value created by BG and NBG firms in terms of asset multiple (5\% significance level) and EBIT multiple (10\% significance level). For sales multiple, no significant difference is observed. The mean value of excess value created by BG firms is observed to be lesser than NBG firms.

${ }^{21}$ Result of ANOVA tests are not reported in this paper. 
Results of Two Way-ANOVA Test performed on business group affiliation and shades of FDI capital are reported in Figures 2(a) (asset multiple), Figure 2(b) (sales multiple) and Figure 2(c) (EBIT multiple). It is observed that for competitiveness shaded FDI capital, marginal means of excess value for NBG firm is higher than BG firm for all three multiples.

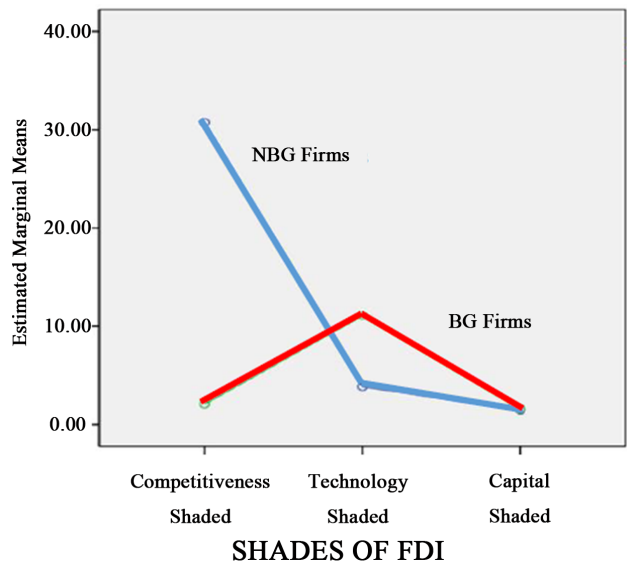

(a)

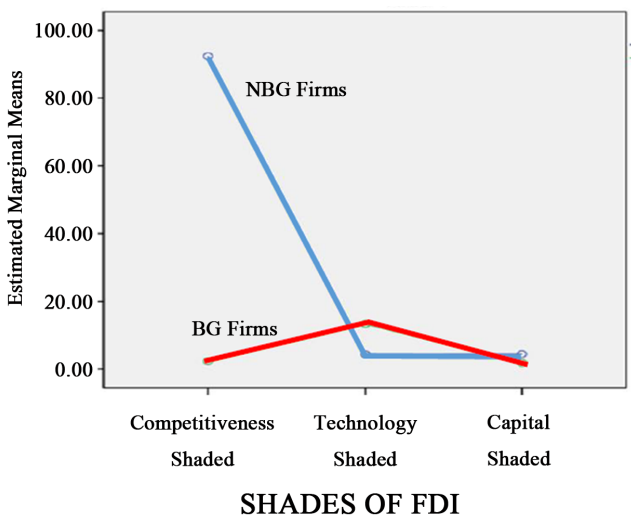

(b)

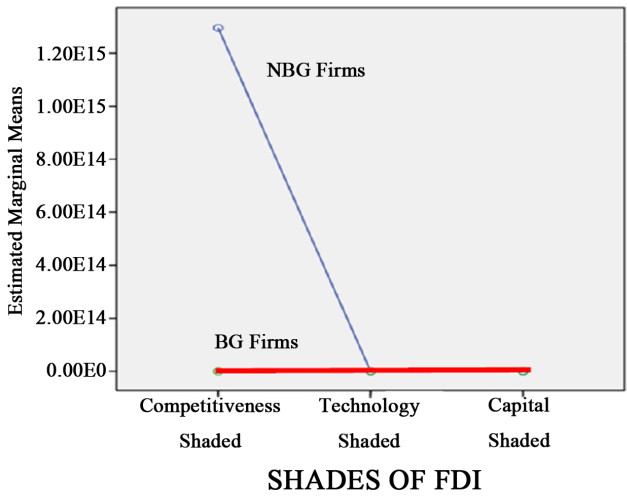

(c)

Figure 2. (a) Two way ANOVA results for asset multiple on bg affiliation and shades of FDI capital; (b) Two way ANOVA results for sales multiple on BG affiliation and shades of FDI capital; (c) Two way ANOVA results for EBIT multiple on BG affiliation and shades of FDI capital. 
Since, the difference between excess value created by BG and NBG differs significantly for competitiveness shaded FDI capital in terms of asset multiple, therefore further analysis is focused on the same. MANOVA test results for excess value (asset multiple) as reported in Table 5 reveals that shade of FDI capital and business group affiliation are significant (10\% significance level) however their interaction is not observed to be significant.

The panel dataset is available for analysis and diagnostic tests are conducted for the same. Hausman test result $(\mathrm{p}>\mathrm{chi} 2=0.035)$ tells that fixed effect model (FEM) is more appropriate for analysis. Further to this, Wald test has been performed and test result $(\mathrm{p}>\mathrm{chi} 2=0.128)$ shows that there is no heteroskedasticity. Since, the dataset set is micro-panel, therefore there is no need to perform serial correlation test and cross sectional dependence test.

The regression estimate of FEM has been presented in Table 6. In this model, Excess value measured as asset multiple is dependent variable and firm characteristics like profitability (EBIT to net sales), asset utilization (fixed asset to net sales) and growth opportunity (capex to net sales) are controlled. These variables

Table 5. Results of MANOVA test (Wilk'S lambda) for excess value (asset multiple).

\begin{tabular}{cccccc}
\hline Independent Factors & Value & F & df & Error df & Sig \\
\hline Intercept & 0.997 & 2.194 & 3 & 2194 & 0.087 \\
FDI Type & 0.997 & 1.189 & 6 & 2788 & 0.081 \\
FDI Type BG Affiliation & 0.998 & 0.82 & 6 & 4388 & 0.554 \\
BG Affiliation & 1 & 0.302 & 3 & 2194 & 0.082 \\
\hline
\end{tabular}

Table 6. Panel data regression estimates: Fixed effect model.

\begin{tabular}{|c|c|c|c|c|c|c|c|c|c|c|}
\hline $\begin{array}{l}\text { Independent } \\
\text { variable }\end{array}$ & $1^{\text {st }}$ Year & $2^{\text {nd }}$ Year & $3^{\text {rd }}$ Year & $4^{\text {th }}$ Year & $5^{\text {th }}$ Year & $6^{\text {th }}$ Year & $7^{\text {th }}$ Year & $8^{\text {th }}$ Year & $9^{\text {th }}$ Year & All Years \\
\hline Constant & $(0.000)$ & $(0.129)$ & $(0.052)$ & $(0.000)$ & $(0.743)$ & $(0.619)$ & $(0.000)$ & $(0.000)$ & $(0.000)$ & $(0.000)$ \\
\hline EBIT to Net Sales & $\begin{array}{l}-0.216 \\
(0.001)\end{array}$ & $\begin{array}{l}-0.097 \\
(0.074)\end{array}$ & $\begin{array}{c}0.168 \\
(0.035)\end{array}$ & $\begin{array}{c}0.235 \\
(0.000)\end{array}$ & $\begin{array}{c}0.348 \\
(0.000)\end{array}$ & $\begin{array}{c}0.240 \\
(0.000)\end{array}$ & $\begin{array}{c}0.303 \\
(0.000)\end{array}$ & $\begin{array}{c}0.411 \\
(0.000)\end{array}$ & $\begin{array}{c}0.137 \\
(0.000)\end{array}$ & $\begin{array}{c}0.101 \\
(0.000)\end{array}$ \\
\hline $\begin{array}{c}\text { Fixed Asset to Net } \\
\text { Sales }\end{array}$ & $\begin{array}{c}0.124 \\
(0.016)\end{array}$ & $\begin{array}{c}0.100 \\
(0.056)\end{array}$ & $\begin{array}{c}0.726 \\
(0.000)\end{array}$ & $\begin{array}{c}0.655 \\
(0.000)\end{array}$ & $\begin{array}{c}0.537 \\
(0.000)\end{array}$ & $\begin{array}{c}0.505 \\
(0.000)\end{array}$ & $\begin{array}{c}0.478 \\
(0.000)\end{array}$ & $\begin{array}{c}0.846 \\
(0.000)\end{array}$ & $\begin{array}{c}0.021 \\
(0.455)\end{array}$ & $\begin{array}{c}0.313 \\
(0.000)\end{array}$ \\
\hline Capex to Net Sales & $\begin{array}{c}0.591 \\
(0.000)\end{array}$ & $\begin{array}{c}0.643 \\
(0.000)\end{array}$ & $\begin{array}{l}-0.184 \\
(0.283)\end{array}$ & $\begin{array}{c}0.095 \\
(0.061)\end{array}$ & $\begin{array}{l}-0.153 \\
(0.000)\end{array}$ & $\begin{array}{l}-0.055 \\
(0.042)\end{array}$ & $\begin{array}{l}-0.020 \\
(0.333)\end{array}$ & $\begin{array}{l}-0.255 \\
(0.000)\end{array}$ & $\begin{array}{c}0.650 \\
(0.000)\end{array}$ & $\begin{array}{c}0.174 \\
(0.000)\end{array}$ \\
\hline Shade of FDI Capital & $\begin{array}{l}-7.569 \\
(0.000)\end{array}$ & & $\begin{array}{l}-9.752 \\
(0.062)\end{array}$ & $\begin{array}{l}11.374 \\
(0.000)\end{array}$ & & & $\begin{array}{c}9.768 \\
(0.000)\end{array}$ & $\begin{array}{l}19.429 \\
(0.000)\end{array}$ & $\begin{array}{l}-14.78 \\
(0.000)\end{array}$ & $\begin{array}{l}-3.686 \\
(0.000)\end{array}$ \\
\hline BG Affiliation & $\begin{array}{l}-0.114 \\
(0.10)\end{array}$ & $\begin{array}{l}-0.059 \\
(0.02)\end{array}$ & $\begin{array}{l}-0.032 \\
(0.06)\end{array}$ & $\begin{array}{l}-0.013 \\
(0.09)\end{array}$ & $\begin{array}{l}-0.032 \\
(0.030)\end{array}$ & $\begin{array}{l}-0.55 \\
(0.018)\end{array}$ & $\begin{array}{l}-0.006 \\
(0.07)\end{array}$ & $\begin{array}{l}-0.027 \\
(0.02)\end{array}$ & $\begin{array}{l}-0.155 \\
(0.00)\end{array}$ & $\begin{array}{l}-0.031 \\
(0.002)\end{array}$ \\
\hline Firm Status & $\begin{array}{c}7.589 \\
(0.000)\end{array}$ & $\begin{array}{c}0.004 \\
(0.932)\end{array}$ & $\begin{array}{l}9.7895 \\
(0.061)\end{array}$ & $\begin{array}{l}-11.35 \\
(0.000)\end{array}$ & $\begin{array}{c}0.016 \\
(0.591)\end{array}$ & $\begin{array}{c}0.014 \\
(0.538)\end{array}$ & $\begin{array}{l}-9.806 \\
(0.000)\end{array}$ & $\begin{array}{c}-19.512 \\
(0.000)\end{array}$ & $\begin{array}{c}14.85 \\
(0.000)\end{array}$ & $\begin{array}{c}3.702 \\
(0.000)\end{array}$ \\
\hline $\mathrm{N}$ & 296 & 265 & 131 & 538 & 680 & 1403 & 1807 & 1794 & 767 & 7689 \\
\hline R square & 0.409 & 0.456 & 0.436 & 0.449 & 0.379 & 0.308 & 0.392 & 0.496 & 0.517 & 0.237 \\
\hline Adj R square & 0.395 & 0.444 & 0.404 & 0.442 & 0.374 & 0.305 & 0.389 & 0.494 & 0.513 & 0.236 \\
\hline
\end{tabular}


are observed to be highly significant for creation of excess value in all investment horizons. The business group affiliation is observed to be highly significant for all investment horizons. The negative coefficient shows that business group affiliation decreases excess value created by the firms. These findings are in line with findings of ANOVA tests (one way and two way).

The effect of business group affiliation has been also estimated through confirmatory factor analysis (CFA) model. The path-diagram for the same is shown in Figure 3. In this model, profitability, asset utilization, growth opportunity and age of the firm are also considered in addition to business group affiliation. The results of CFA are reported in Table 7, which reveals that these factors are highly significant. The negative coefficient of business group affiliation is in confirmation with the result obtained through regression estimate in FEM.

Above analysis indicates that business group affiliation has negative effect on the value created by firms. There is strong evidence for asset multiple but weak evidence for EBIT multiple. For sales multiples, no evidence is observed. This

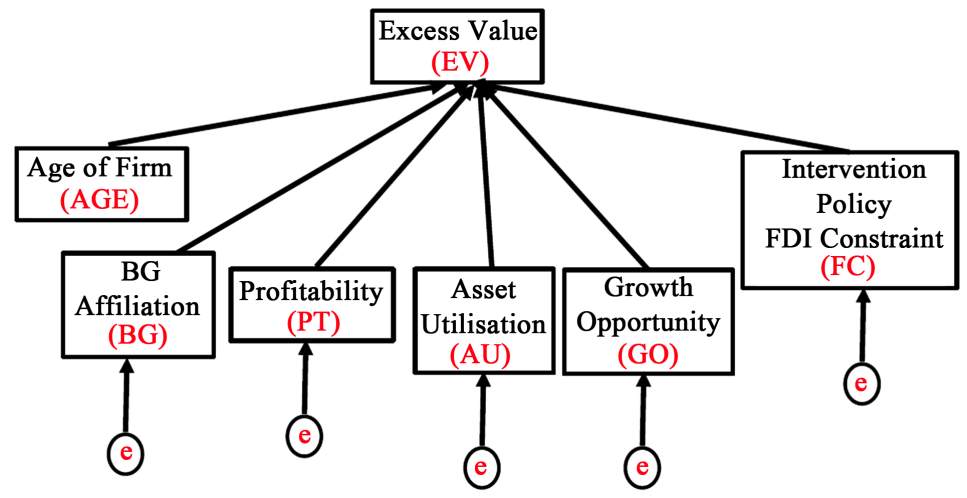

Figure 3. Path diagram for confirmatory factor analysis (CFA).

Table 7. Results of confirmatory factor analysis.

\begin{tabular}{|c|c|c|c|c|c|}
\hline & & Coefficient & OIM Std Error & $\mathrm{Z}$ & $\mathbf{P}>|\mathrm{Z}|$ \\
\hline \multirow{2}{*}{ AGE } & $\mathrm{EV}$ & \multicolumn{4}{|c|}{1 (Constrained) } \\
\hline & Const & 192.34 & 1.234 & 57.34 & 0.00 \\
\hline \multirow{2}{*}{ Business Group } & $\mathrm{EV}$ & -2.34 & 1.62 & 3.5 & 0.00 \\
\hline & Const & 90.37 & 1.89 & 40.23 & 0.00 \\
\hline \multirow{2}{*}{ Profitability } & $\mathrm{EV}$ & 3.23 & 1.45 & 5.5 & 0.00 \\
\hline & Const & 72.45 & 1.46 & 58.25 & 0.00 \\
\hline \multirow{2}{*}{ Asset Utilization } & $\mathrm{EV}$ & 0.98 & 2.23 & 3.24 & 0.00 \\
\hline & Const & 89.75 & 1.67 & 9.35 & 0.00 \\
\hline \multirow{2}{*}{ Growth Opportunity } & $\mathrm{EV}$ & 2.45 & 2.34 & 6.5 & 0.00 \\
\hline & Const & 72.65 & 2.64 & 8.92 & 0.00 \\
\hline \multirow{2}{*}{ Shade of FDI Capital } & $\mathrm{EV}$ & 0.42 & 0.12 & 3.5 & 0.00 \\
\hline & Const & 19.23 & 2.81 & 8.72 & 0.00 \\
\hline
\end{tabular}


indicates that asset utilization is the most important parameters of firm for value creation. A firm can increase its value by increasing asset utilization. Increasing EBIT or better cost management practice of the firm may help in creating excess value. Since all firms are competing against each other in the same industry with similar market conditions, therefore increasing sales only is not sufficient way to create excess value. Therefore, in order to create excess value, a firm needs to focus on asset utilization followed by better cost management practice.

The above discussed analysis provides strong evidence of negative effect of business group affiliation for firms with competitiveness shaded FDI capital. Therefore, hypothesis $\mathrm{H}_{1 \mathrm{c}}$ is confirmed and $\mathrm{H}_{0 \mathrm{c}}$ is not confirmed.

This result is in contrast to the proposed hypotheses on the basis of the literature. The negative effect of business group affiliation has been widely reported in literature. Khanna and Palepu provide sufficient reasons for the same [15]. According to them, this is possible by sharing of resources, having strategic ties with group members leading to lower efficiency, intra-group financing, cross-subsidization and misallocation of resources. This is issue of further investigation that which mode of tunneling prevails in Indian economy. This clearly indicates that FDI investor should prefer stand-alone firm than business group affiliated firm. This also serves the purpose of Indian government especially when the economy is dominated by business group. Infusion of FDI capital to stand-alone firm will increase competitiveness and they will be in better position to compete with business group affiliated firm. This increase in competition will lead to increases competitiveness of Indian industry.

\subsection{Technology Shaded FDI Capital}

For technology shaded FDI capital, no statistically significant difference is observed between excess value created by BG and NBG firms. This holds true for all three measures of excess value i.e. asset multiple, sales multiple and EBIT multiple.

Results of Two Way-ANOVA Test (Figures 2(a)-(c)), also support the above empirical evidence. Marginal means of excess value for $\mathrm{BG}$ firms is higher than NBG firm however it is not significant. Hence, both hypotheses $\mathrm{H}_{0 \mathrm{a}}$ and $\mathrm{H}_{1 \mathrm{a}}$ are not confirmed.

This phenomenon can be explained on the bass of demonstration effect and technology transfer within domestic firms. Demonstration effect reduces competitive advantage of having access to superior technology (on account of FDI) as competitor follows very similar process. This is possible only if firms having access to superior technology is not able to protect its intellectual property due to poor IPR regime.

\subsection{Capital Shaded FDI Capital}

ANOVA test result for capital shaded FDI capital very similar to technology shaded FDI capital. As no statistically significant difference is observed between 
excess value created by BG and NBG firms. This holds true for all three measures of excess value i.e. asset multiple, sales multiple and EBIT multiple.

For capital shaded FDI capital, results of Two Way-ANOVA Test (Figures 2(a)-(c)) indicates that marginal means of excess value for BG firm is lower than NBG but the difference is not observed to be statistically significant. On the basis of above mentioned empirical evidences hypotheses $\mathrm{H}_{1 b}$ and $\mathrm{H}_{0 \mathrm{~b}}$ are not confirmed. This phenomenon can be explained on the basis of reduction in cost of capital due to availability of internal market for BG firm. It is expected that excess value can be created if cost of capital is reduced. Therefore, internal capital market of business group is not effective in reducing cost of capital and no excess value is being created.

\section{Discussion}

This research work is based on theoretical premise of having effect of business group affiliation to infuse three components of FDI (technology, capital and competitiveness) in domestic economy. This theoretical framework offers opportunity to design and develop policy instruments.

The classification of FDI can be useful for investors as it is based on the need of the host economy. This classification can also be used by host government to attract specific set of investors as per need of economy.

This study suffers from limitation of data. The number of observation under three categories of FDI is not equal.

This Research work can be extended for comparison of more than one host economy.

\section{Conclusions}

The competitiveness shades of FDI capital are observed highly significant for business group affiliated firm. The difference in excess value created by business group affiliated and stand-alone firm is highly significant and mean value of excess value is observed lower for business group affiliated firm. These empirical evidences are in favor of tunneling effect of business group affiliation for competitiveness shades of FDI capital. This result is in line with findings of Bertrand et al. (non-operating profit) [8]. Controlling value creating factors like growth opportunity, asset utilization and profitability, it is observed that tunneling effect of business group affiliation is highly significant for competitiveness shade of FDI capital.

There is strong evidence that FDI investors' fund is expropriated by domestic business group when host economy has sufficient capital and technology and foreign investor is intending to create excess value on account of their higher efficiency (competitiveness shaded FDI capital). It is advisable for efficient FDI investors to prefer stand-alone firm than business group. This is also evident from the dataset that mean FDI ownership in business affiliated firm is less than NBG firm. The number of BG firm with FDI capital is also less than number of 
NBG firms with FDI capital. This clearly indicates that foreign investor preference for NBG firms will help home economy in increasing the competition between NBG and BG firms. Other FDI investors (with technology and capital shaded FDI capital) should make investment in business group with high profit, growth and asset utilization. These findings are important for foreign investor making investment in emerging economy like India, where restrictions on ownership and capital are used as policy instrument to regulate foreign investment.

\section{Conflicts of Interest}

The authors declare no conflicts of interest regarding the publication of this paper.

\section{References}

[1] Friedman, E., Johnson, S. and Mitton, T. (2003) Propping and Tunneling. Journal of Comparative Economics, 31, 732-750. https://doi.org/10.1016/j.jce.2003.08.004

[2] Cheung, Y. L. Rau, P.R. and Stouraitis, A. (2006) Tunneling, Propping and Expropriation: Evidence from Connected Party Transactions in Hong Kong. Journal of Financial Economics, 82, 343-386. https://doi.org/10.1016/j.jfineco.2004.08.012

[3] Riyanto, Y.E. and Toolsema, L.A. (2008) Tunneling and Propping: A Justification for Pyramidal Ownership. Journal of Banking and Finance, 32, 2178-2187. https://doi.org/10.1016/j.jbankfin.2007.12.044

[4] Dow, S. and McGuire, J. (2009) Propping and Tunneling: Empirical Evidence from Japanese Keirestu. Journal of Banking and Finance, 33, 1817-1828. https://doi.org/10.1016/j.jbankfin.2009.05.012

[5] Peng, W.Q., Wei, K.C.J. and Yang, Z. (2011) Tunneling or Propping: Evidence from Connected Transactions in China. Journal of Corporate Finance, 17, 306-325. https://doi.org/10.1016/j.jcorpfin.2010.08.002

[6] Johnson, S., Peter, B., Alasdair, B. and Eric, F. (2000) Corporate Governance in the Asian Financial Crisis. Journal of Financial Economics, 58, 141-186. https://doi.org/10.1016/S0304-405X(00)00069-6

[7] Glaeser, E., Johnson, S. and Shleifer, A. (2001) Coase versus the Coasians. The Quarterly Journal of Economics, 116, 853-899. https://doi.org/10.1162/00335530152466250

[8] Bertrand, M., Mehta, P. and Mullainathan, S. (2002). Ferreting out Tunneling: An Application to Indian Business Groups. Quarterly Journal of Economics, 117, 121-148. https://doi.org/10.1162/003355302753399463

[9] Lemmon, M.L. and Lins, K.V. (2003) Ownership Structure, Corporate Governance, and Firm Value: Evidence from the East Asian Financial Crisis. Journal of Finance, 58, Issue 4.

[10] Silva, F., Majluf, N. and Paredes, F. (2006) Family Ties, Interlocking Directors and Performance of Business Groups in Emerging Countries: The Case of Chile. Journal of Business Research, 59, 315-321. https://doi.org/10.1016/j.jbusres.2005.09.004

[11] Ito, T. and Krueger, A.O., Eds. (2004) Governance, Regulation, and Privatization in the Asia-Pacific Region, NBER East Asia Seminar on Economics, Volume 12.

[12] Riyanto, Y.E. and Toolsema, L.A. (2008) Tunneling and Propping: A Justification for Pyramidal Ownership. Journal of Banking \& Finance, 32, 2178-2187.

https://doi.org/10.1016/j.jbankfin.2007.12.044 
[13] McGuire, J. and Dow, S. (2009) Japanese keiretsu: Past, Present, Future. Asia Pacific Journal of Management, 26, 333-351. https://doi.org/10.1007/s10490-008-9104-5

[14] Peng, W.Q., Wei, K.C.J. and Yang, Z.S. (2011) Tunneling or Propping: Evidence from Connected Transactions in China. Journal of Corporate Finance, 17, 306-325. https://doi.org/10.1016/j.jcorpfin.2010.08.002

[15] Khanna, T. and Palepu, K. (2000) Is Group Affiliation Profitable in Emerging Markets? An Analysis of Diversified Indian Business Groups. Journal of Finance, 55, 867-891. https://doi.org/10.1111/0022-1082.00229

[16] Khanna, T. and Rivkin, J. (2001) Estimating the Performance Effects of Business Groups in Emerging Markets. Strategic Management Journal, 22, 45-74. https://doi.org/10.1002/1097-0266(200101)22:1<45::AID-SMJ147>3.0.CO;2-F

[17] Simone, F.N. and Sorsa, P. (1999) A Review of Capital Account Restrictions in Chile in the 1990s. IMF Working Paper, 99/52, International Monetary Fund, Washington DC.

[18] Asian Development Bank (2002) Key Indicators of Asian and Pacific Countries 2002. ADB Publications, Mandaluyong.

[19] Karabay, B. (2010) Foreign Direct Investment and Host Country Policies: A Rationale for Using Ownership Restrictions. Journal of Development Economics, 93, 218-225. https://doi.org/10.1016/j.jdeveco.2009.11.003

[20] Dasgupta, S. and Sengupta, K. (1995) Optimal Regulation of MNEs and Government Revenues. Journal of Public Economics, 58, 215-234. https://doi.org/10.1016/0047-2727(94)01474-3

[21] Li, M. and Wong, Y. (2003) Diversification and Economic Performance: An Empirical Assessment of Chinese Firms. Asia Pacific Journal of Management, 20, 243-265. https://doi.org/10.1023/A:1023804904383

[22] Frynas, J.G., Pigman, G.A. and Mellahi, K. (2006) First Mover Advantages in International Business and Firm-Specific Political Resources. Strategic Management Journal, 27, 321-345. https://doi.org/10.1002/smj.519

[23] Kogut, B. and Singh, H. (1988) The Effect of National Culture on the Choice of Entry Mode. Journal of International Business Studies, 19, 411-432. https://doi.org/10.1057/palgrave.jibs.8490394

[24] Bell, D., Dow, S., King, D. and Massie, N. (1996) Hume Papers on Public Policy. http://coolbookre.com/financing-devolution-read-unlimited-free-e-books.pdf

[25] Vernon, R. (1966) International Investment and International Trade in the Product Cycle. Quarterly Journal of Economics, 80, 190-207. https://doi.org/10.2307/1880689

[26] Teasley, B., Lund, A. and Bennett, R. (1996) Interactive Television: A New Challenge for HCI. Conference Companion on Human Factors in Computing Systems. Common Ground, Vancouver, 13-18 April 1996, 356. https://doi.org/10.1145/257089.257366

[27] Camp, S.M. and Sexton, D.L. (1992) Technology Transfer and Value Creation: Extending the Theory beyond Information Exchange. Technology Transfer, 17, 68-76. https://doi.org/10.1007/BF02199480

[28] Bell, J.H.J. (1996) Single or Joint Venturing? A Comprehensive Approach to Foreign Entry Mode Choice. Avebury, Aldershot.

[29] Pitelis, C.N. and Vasilaros, V. (2010) The Determinants of Value and Wealth Creation at the Firm, Industry, and National Levels: A Conceptual Framework and Evidence. Contributions to Political Economy, 29, 33-58. 
https://doi.org/10.1093/cpe/bzq003

[30] Khanna, T. and Fisman, R. (1999) Is Trust a Historical Residue? Information Flows and Trust Levels. Journal of Economic Behavior and Organization, 38, 79-92. https://doi.org/10.1016/S0167-2681(98)00123-1

[31] Granovetter, M. (2005) Business Groups and Social Organization. In: Smelser, N.J. and Swedberg, R., Eds., The Handbook of Economic Sociology, 2nd Edition, Princeton University Press, Princeton, 429-450.

[32] Morck, R. and Yeung, B. (2003) Agency Problems in Large Family Business Groups. Entrepreneurship Theory and Practice, 271, 367-382. https://doi.org/10.1111/1540-8520.t01-1-00015

[33] Gopalan, R., Nanda, V. and Seru, A. (2007) Affiliated Firms and Financial Support: Evidence from Indian Business Groups. Journal of Financial Economics, 86, 759-795. https://doi.org/10.1016/j.jfineco.2006.09.008

[34] Lewellen, W.G. (1971) A Pure Financial Rationale for the Conglomerate Merger. Journal of Finance, 26, 521-537. https://doi.org/10.1111/j.1540-6261.1971.tb00912.x

[35] Ferris, S.K. and Kim, P.K. (2003) The Costs (and Benefits?) of Diversified Business Group: The Case of Korean Chaebols. Journal of Banking and Finance, 27, 251-273. https://doi.org/10.1016/S0378-4266(01)00248-5

[36] Dahlquist, M.R. and Ran, G.K. (2001) Direct Foreign Ownership, Institutional Investors, and Firm Characteristics. Journal of Financial Economics, 59, 413-440. https://doi.org/10.1016/S0304-405X(00)00092-1

[37] Nicodano, G. and Chiesa, G. (2003) Privatization and Financial Market Development: Theoretical Issues, FEEM Note di Lavoro.

[38] Khanna, T. and Palepu, K. (1999) Emerging Market Business Groups, Foreign Investors, and Corporate Governance. NBER Working Paper No. 6955.

[39] Guillén, M.F. (2000) Business Groups in Emerging Economies: A Resource Based View. Academy of Management Journal, 43, 362-380.

[40] Gerlach, M.L. (1992) Alliance Capitalism: The Social Organization of Japanese Business. University of California Press, Berkeley.

[41] Keister, L.A. (1998) Engineering Growth: Business Groups Structure and Firm Performance in China's Transition Economy. American Journal of Sociology, 104, 404-440. https://doi.org/10.1086/210043

[42] Chang, S.-J. and Choi, U. (1988) Strategy, Structure, and Performance of Korean Business Groups: A Transaction Cost Approach. Journal of Industrial Economics, 37, 141-158. https://doi.org/10.2307/2098561

[43] Chang, S.-J. and Hong, J. (2000) Economic Performance of Group-Affiliated Companies in Korea: Intra-Group Resource Sharing and Internal Business Transactions. Academy of Management Journal, 43, 429-448.

[44] Khanna, T. and Rivkin, J. (2000) Ties That Bind Business Groups: Evidence from an Emerging Market. HBS Strategy Unit Working Paper No. 00-068. https://ssrn.com/abstract=238991 http://dx.doi.org/10.2139/ssrn.238991 https://doi.org/10.2139/ssrn.238991

[45] Weidenbaum, M. and Hughes, S. (1996) The Bamboo Network: How Expatriate Chinese Entrepreneurs Are Creating a New Economic Superpower in Asia. Free Press, New York.

[46] Granovetter, M. (2005) The Impact of Social Structure on Economic Outcomes. Journal of Economic Perspectives, 19, 3-50. https://doi.org/10.1257/0895330053147958 
[47] Luo, X. and Chung, C.-N. (2005) Keeping It All in the Family: The Role of Particularistic Relationships in Business Group Performance during Institutional Transition. Administrative Science Quarterly, 50, 404-439. https://doi.org/10.2189/asqu.2005.50.3.404

[48] Fazzari, S., Hubbard, R.G. and Petersen, B. (1988) Financing Constraints and Corporate Investment. Brookings Papers on Economic Activity, 1, 141-195. https://doi.org/10.2307/2534426

[49] Hoshi, T., Kashyap, A. and Scharfstein, D. (1991) Corporate Structure, Liquidity and Investment: Evidence from Japanese Industrial Groups. Quarterly Journal of Economics, 106, 33-60. https://doi.org/10.2307/2937905

[50] Shin, H.H. and Stulz, R. (1998) Are Internal Capital Markets Efficient? Quarterly Journal of Economics, 113, 531-552. https://doi.org/10.1162/003355398555676

[51] Maurer, N. and Sharma, T. (2001) Enforcing Property Rights through Reputation: Mexico's Early Industrialization, 1878-1913. The Journal of Economic History, 61, 950-973. https://doi.org/10.1017/S0022050701042048

[52] Goldberg, P., Khandelwal, N. and Pavcnikand Topalova, P. (2010) Multi-Product Firms and Product Turnover in the Developing World: Evidence from India. Review of Economics and Statistics, 92, 1042-1049.

https://doi.org/10.1162/REST_a_00047

[53] Khanna, T. and Palepu, K. (2000) The Future of Business Groups in Emerging Markets: Long-Run Evidence From Chile. Academy of Management Journal, 43, 268-285.

[54] Khanna, T., Palepu, K.G. and Sinha, J. (2005) Strategies That Fit Emerging Markets. Harvard Business Review, 83, 63-74.

[55] Fisman, R. and Khanna, T. (2004) Facilitating Development: The Role of Business Groups. World Development, 32, 609-628.

https://doi.org/10.1016/j.worlddev.2003.08.012

[56] Goldberg, P., Khandelwal, A., Pavcnik, N. and Topalova, P. (2009) Trade Liberalization and New Imported Inputs. American Economic Review, 99, 494-500. https://doi.org/10.1257/aer.99.2.494

[57] Berger, P.G. and Ofek, E. (1995) Diversification's Effect on Firm Value. Journal of Financial Economics, 37, 39-65. https://doi.org/10.1016/0304-405X(94)00798-6

[58] Anderson, R.L. and Bancroft, T.A. (1952) Statistical Theory in Research. McGraw Hill, New York.

[59] Scheffe, H. (1959) The Analysis of Variance. John Wiley and Sons, New York.

[60] Searle, S.R. (1971) Linear Models. John Wiley and Sons, New York. 